Journal of the Egyptian Society of Parasitology, Vol.43, No.2, August 2013

J. Egypt. Soc. Parasitol., 43(2), 2013: 399 - 406

\title{
IMPACT OF PHYSICAL AND CHEMICAL CHARACTERISTICS OF BREEDING SITES ON MOSQUITO LARVAL ABUNDANCE AT ISMAILIA GOVERNORATE, EGYPT
}

\author{
By \\ IMAN MOHAMED BAHGAT \\ Department of Zoology, Faculty of Science, Port Said University, Egypt
}

Abstract

The distribution and monthly abundance of mosquito larvae in released water, drainage canals and sewage water tanks in Ismailia governorate were investigated. The results obtained indicated the presence of five culicine (Culex. pipiens, $C x$. pusillus, Cx. perexiguus, Cx. theleri and Ochlerotatus. caspius) and two anopheline (Anopheles. multicolor and An. pharoensis) mosquito species. Significantly higher larval density was recorded in sewage water $(\mathrm{n}=5534 ; 46.08 \%)$ as compared with released water $(\mathrm{n}=2903 ; 24.17 \%)$ and drainage water $(\mathrm{n}=3573 ; 29.75 \%)$. Culex pipiens was the most dominant mosquito species in the three habitats. The effects of environmental parameters including $\mathrm{pH}$, biological and chemical oxygen demands, day time water temperature, plant growth, salinity, total organic matter and concentrations of heavy metals on larval population density were investigated. The positive correlations observed between heavy metals concentrations in the three habitats suggested relative uniformity of the sources of metal pollutants. Culex pipiens larvae demonstrated high tolerance to elevated levels of heavy metals in sewage water and compensatory effects of high nutrient levels generally associated with sewage or domestic waste. High densities of culicine larvae were accompanied by low density of anopheline larvae. This was attributed to water chemistry \& competitive interactions.

Key words: Egypt, Mosquito, Culex pipiens, larvae pollutants, heavy metals

\section{Introduction}

The mosquito larval habitats, such as temporary or permanent bodies of water, can vary in quality along gradients of resources, predation and water chemistry which affect both female oviposition choice and larval survival (Clements, 1999). The study of not only the fluctuations of adult populations, but also the factors affecting larval abundance and distributions are important. Understanding of these factors is considered fundamental to the ability to predict transmission rates of certain diseases and for vector population control. Furthermore larval habitats are important determinants of adult distribution and abundance (Service 1989; 1995).

The present study aimed to investigate the influence of physical and chemical characteristics of mosquito larval breeding sites in Ismailia Governorate on both temporal and spatial variations of mosquito larval abundance. 


\section{Materials and Methods}

Study localities, nature of breeding sites and larval sampling: Ismailia Governorate is located north east of Egypt at $31^{\circ} \mathrm{N} ; 30{ }^{\circ} \mathrm{S} ; 32.31^{\circ} \mathrm{E}$ and $31.42^{\circ} \mathrm{W}$. Three localities were selected for the study including Ismailia locality, Faied and West Kantara (Fig 1). Each of these is characterized by different water bodies serving as mosquito larval breeding places. Ismailia locality has scattered collections of released water resulting from the increase in level of ground water. Such water was found under and between buildings as shallow (10-25 cm depth), stagnant, non-turbid spots subjected to moderate and weak light with few plantations growing on its edges. Faied locality is characterized by the presence of drained canals resulting from the agricultural irrigation activities ranging from $50-100 \mathrm{~cm}$ in width containing greatly turbid, slowly flowing, semi shaded water characterized by growth of weed grass and floating vegetation. West Kantara contains hard tanks from 2-3 meters in depth and lined with cement layer except at the base. These tanks are built underground, behind the houses. Each tank has an upper opening through which the sewage water is collected. Such water is stagnant, turbid, subjected to faint light and without any growing plants.

Larval sampling was carried out monthly from January to December (2008) from fixed breeding sites representing the three habitats. Collected larvae from the different localities as well as water samples were put in plastic bags and transported to the laboratory for counting and identification following to Key prepared (Gad, 1963). Relative monthly larval density was estimated as the number/dip using a net dipper (WHO, 1975).

Measurement of environmental variables: Electrical conductivity (E.C.) of $5 \mathrm{ml}$ saturated water samples expressed as $\left(\mathrm{dsm}^{-1}\right)$ was measured using conductivity meter (Richard et al, 1954). The hydrogen ion concentration $(\mathrm{pH})$ was determined by $\mathrm{pH}$ meter (Page et al, 1982). Biological and chemical oxygen demands (D.O mg/L) were measured (APHA, 1985; AOAC, 1995). Chemical oxygen demand (COD mg/L) was used to measure the organic matter contents of water (Jackson, 1958). The total suspended solid (TSS mg/L) was determined by the glass filter paper filtration method (APHA, 1985). The heavy metals concentrations were done by Plasma Optical Emission-Mass Spectro-photometer (POEMS III), at the Central Laboratory, Faculty of Agriculture, Suez Canal University; and results were expressed as (mg/L; ppm).

Statistical analysis: The SPSS software version 11.5 was adopted. One way analysis of variance (ANOVA) and Chi-square analysis were used to compare larval densities and heavy metals concentrations in the three habitats. Results were considered significant at $\mathrm{P}<0.05$. Pearson correlation coefficient (r) was used to test relationships between metals concentrations in the three habitats. 


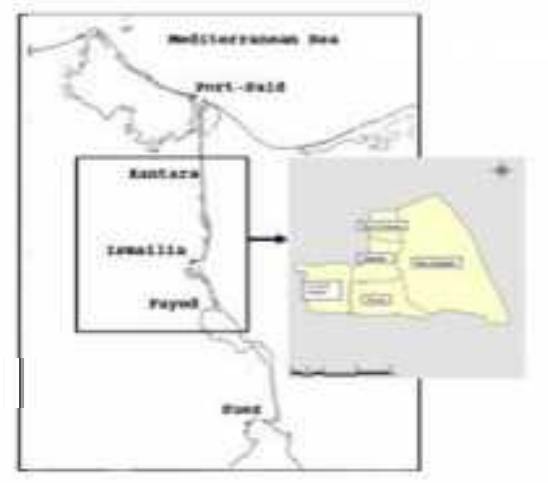

Fig 1: Map of different breeding sites of mosquito larval at Ismailia Governorate

Table 1: Chemical and physical characters of larval breeding sites at Ismailia G.

\begin{tabular}{|l|c|c|c|}
\hline Type of habitat Parameters & Released water & Agricultural drainage water & Sewage water \\
\hline $\mathrm{pH}$ & 7.9 & 7.8 & 7.3 \\
${\text { E.C. }\left(\mathrm{dsm}^{-1}\right)}_{\text {Salinity }}^{-1}$ & 2.61 & 1.65 & 3.69 \\
\hline Heavy metals: ppm & 698.1 & 277.3 & 198.4 \\
$\mathrm{Zn}$ & 0.011 & 0.033 & \\
$\mathrm{Fe}$ & 0.050 & 0.11 & 0.16 \\
$\mathrm{Cd}$ & 0.001 & 0.001 & 0.71 \\
$\mathrm{Cu}$ & 0.002 & 0.041 & 0.01 \\
$\mathrm{~Pb}$ & 0.001 & 0.003 & 0.07 \\
$\mathrm{Mn}$ & 0.030 & 0.025 & 0.23 \\
\hline TOMC & 6 & 10 & 25 \\
$\mathrm{COD}$ & 19 & 32 & 4 \\
$\mathrm{~B} 0 \mathrm{D}$ & 18 & 38 & 52 \\
\hline
\end{tabular}

$\mathrm{pH}=$ Hydrogen ion concentration , E.C. $=$ Electrical conductivity, TOMC = Total organic matter concentration, $\mathrm{COD}=$ Chemical oxygen demand, $\mathrm{B} 0 \mathrm{D}=$ Biological oxygen demand

\section{Results}

A total of 12010 mosquito larvae were collected from the three habitats. Where $2903(24.17 \%), 3573(29.75 \%)$ and $5534(46.08 \%)$ from released water, drainage canals and sewage water respectively (Fig. 2). One way ANOVA showed that mosquito density in sewage water was significantly higher than other habitats $\left(\mathrm{F}_{2,35}=18.4 \mathrm{P}<\right.$ 0.001). Larvae collections were five species; Culex pipiens $(\mathrm{n}=10776$; $89.73 \%)$, Cx. pusillus $(\mathrm{n}=392 ; 3.26 \%)$, $C x$. perexiguus $(\mathrm{n}=306 ; 2.55 \%), C x$. theleri $(\mathrm{n}=257 ; 2.13 \%)$, Ochlerotatus caspius $(\mathrm{n}=83 ; 0.69 \%)$. Two anopheline species were Anophles multicolor $(\mathrm{n}=143 ; 1.19 \%)$ and An. pharoensis $(\mathrm{n}=53 ; 0.44 \%)$.

$C x$. pipiens was the most dominant species in the three habitats $(\mathrm{F}=22.8$; $\mathrm{P}<0.001)$. The relative densities were $89.5 \%, 89.7 \%$ and $89.8 \%$ of total collected larvae (Tab. 3; Fig. 2) and their abundance significantly varied across time (Fig. 3) at various physical and chemical conditions of breeding sites (Tab. 1; Fig. 4 a, b, c).

Chi-square analysis indicated that $C x$. pipiens larvae were more abundant in 
August $\left(X^{2}=204\right.$; d. f. $\left.=11 ; P<0.001\right)$, October $\left(X^{2}=299\right.$ d. f. $\left.=11 ; \mathrm{P}<0.001\right)$ and June $\left(\mathrm{X}^{2}=244\right.$; d. f. $\left.=11 \mathrm{P}<0.001\right)$ in released, drainage, and sewage water respectively. The $\mathrm{pH}$ was (7-7.3) and slight difference was observed in the temperature of the three habitats being $36.3^{\circ} \mathrm{C} ; 35.1^{\circ} \mathrm{C}$ for the released water and sewage water respectively, drainage water had a markedly lower temperature $\left(18.2^{\circ} \mathrm{C}\right)$. In the study period, total organic matter values (TOMC) was relatively higher in sewage water (25 ppm) compared to released (6 ppm) and drainage water $(10 \mathrm{ppm})$. The value of chemical oxygen demand (COD) was relatively higher in drainage water (32 $\mathrm{ppm})$ compared to released water (19 ppm) and sewage water (4ppm). On the other hand, the biological oxy- gen demand was relatively higher in sewage water $(52 \mathrm{ppm})$ than released (18 ppm) and drainage ones (38 ppm). Released water was more saline (698.1 $\mathrm{mg} / \mathrm{L})$ than drainage $(277.3 \mathrm{mg} / \mathrm{L})$ and sewage water $(198.4 \mathrm{mg} / \mathrm{L})$.

Sewage water had significantly higher conc. of heavy metals compared to released $(\mathrm{F}=0.005 ;$ d. f. $=5 ; \mathrm{P}<0.001)$ and drainage water $(\mathrm{F}=0.002 ; \mathrm{d}$. f. $=5$; $\mathrm{P}<0.001)$. Comparable metal concentrations were recorded in both released and drainage water $(\mathrm{F}=3.9 ; \mathrm{P}=0.07$; Tab. 1). Iron conc. was higher than other metals in all habitats. But, concentrations of the remaining recorded metals were highly positively correlated where the values of the correlation coefficient (r) ranged from 0.8 to 0.9 (Tab. 4).

Table 2: Mosquito species diversity in three habitats

\begin{tabular}{|c|c|c|c|c|c|c|c|}
\hline Water & $\begin{array}{c}\text { Cx. } \\
\text { pipiens }\end{array}$ & $\begin{array}{c}\text { Cx. } \\
\text { pusillus }\end{array}$ & $\begin{array}{c}\text { Cx. } \\
\text { perexiguus }\end{array}$ & $\begin{array}{c}\text { Cx. } \\
\text { theleri }\end{array}$ & $\begin{array}{c}\text { Oc. } \\
\text { caspius }\end{array}$ & $\begin{array}{c}\text { An. } \\
\text { multicolor }\end{array}$ & $\begin{array}{c}\text { An. } \\
\text { pharoensis }\end{array}$ \\
\hline Release & 2599 & 152 & 0 & 0 & 83 & 69 & 0 \\
Drainage & 3206 & 240 & 0 & 0 & 0 & 74 & 53 \\
Sewage & 4971 & 0 & 306 & 257 & 0 & 0 & 0 \\
\hline Total & 10776 & 392 & 306 & 257 & 83 & 143 & 53 \\
\hline
\end{tabular}

Table 3: Monthly abundance of mosquito species in habitats at Ismailia G., 2008

\begin{tabular}{|c|c|c|c|c|c|c|c|c|c|c|c|}
\hline Water & \multicolumn{9}{|c|}{ Released } & \multicolumn{3}{|c|}{ Agricultural drainage } & \multicolumn{3}{|c|}{ Sewage } \\
\hline Sp. & $\begin{array}{c}\text { Cx. } \\
\text { pipiens }\end{array}$ & $\begin{array}{c}\text { An. } \\
\text { multi- } \\
\text { color }\end{array}$ & $\begin{array}{c}\text { Cx. } \\
\text { pus- } \\
\text { illus }\end{array}$ & $\begin{array}{c}\text { Oc. } \\
\text { caspius }\end{array}$ & $\begin{array}{c}\text { Cx. } \\
\text { pipiens }\end{array}$ & $\begin{array}{c}\text { An. } \\
\text { multi- } \\
\text { color }\end{array}$ & $\begin{array}{c}\text { Cx. } \\
\text { pus- } \\
\text { illus }\end{array}$ & $\begin{array}{c}\text { An. } \\
\text { pharo- } \\
\text { ensis }\end{array}$ & $\begin{array}{c}\text { Cx. } \\
\text { pipi- } \\
\text { ens }\end{array}$ & $\begin{array}{c}\text { Cx. } \\
\text { perex- } \\
\text { iguus }\end{array}$ & $\begin{array}{c}\text { Cx. } \\
\text { thel- } \\
\text { eri }\end{array}$ \\
\hline Jan & 160 & 6 & 9 & 3 & 153 & 5 & 9 & 4 & 324 & 21 & 15 \\
\hline Feb & 98 & 3 & 6 & 4 & 168 & 5 & 10 & 4 & 235 & 14 & 13 \\
\hline Mar. & 138 & 4 & 7 & 4 & 161 & 4 & 11 & 3 & 347 & 22 & 17 \\
\hline April & 197 & 5 & 11 & 6 & 307 & 9 & 21 & 5 & 508 & 30 & 27 \\
\hline May & 205 & 6 & 13 & 7 & 301 & 8 & 22 & 4 & 548 & 34 & 27 \\
\hline June & 216 & 6 & 12 & 7 & 304 & 8 & 24 & 5 & 553 & 33 & 29 \\
\hline Jul. & 256 & 7 & 16 & 9 & 210 & 6 & 14 & 4 & 410 & 25 & 21 \\
\hline Aug. & 337 & 9 & 19 & 10 & 331 & 6 & 26 & 5 & 442 & 28 & 24 \\
\hline Sept. & 270 & 6 & 16 & 9 & 342 & 5 & 36 & 5 & 453 & 27 & 26 \\
\hline Oct. & 252 & 6 & 16 & 7 & 368 & 7 & 21 & 5 & 420 & 28 & 19 \\
\hline Nov. & 244 & 6 & 14 & 9 & 322 & 6 & 28 & 5 & 405 & 24 & 22 \\
\hline Dec. & 226 & 5 & 13 & 8 & 239 & 5 & 18 & 4 & 326 & 20 & 17 \\
\hline Total & 2599 & 69 & 152 & 83 & 3206 & 74 & 240 & 53 & 4971 & 306 & 257 \\
\hline$\%$ & 89.5 & 2.4 & 5.2 & 2.9 & 89.7 & 2.1 & 6.7 & 1.5 & 89.8 & 5.5 & 4.6 \\
\hline
\end{tabular}


Table 4: Person correlation coefficients (r) for correlation between heavy metals concentrations in water

\begin{tabular}{|c|c|c|c|c|c|c|}
\hline Metal & $\mathrm{Zn}$ & $\mathrm{Fe}$ & $\mathrm{Cd}$ & $\mathrm{Cu}$ & $\mathrm{Pb}$ & $\mathrm{Mn}$ \\
\hline $\mathrm{Zn}$ & 1 & & & & & \\
\hline $\mathrm{Fe}$ & 0.998493 & 1 & & & & \\
\hline $\mathrm{Cd}$ & 0.990604 & 0.996616 & 1 & & & \\
\hline $\mathrm{Cu}$ & 0.891067 & 0.864818 & 0.820621 & 1 & & \\
\hline $\mathrm{Pb}$ & 0.997158 & 0.99979 & 0.998092 & 0.854338 & 1 & 1 \\
\hline $\mathrm{Mn}$ & 0.987453 & 0.994631 & 0.999771 & 0.808216 & 0.996544 & 1 \\
\hline
\end{tabular}

\section{Discussion}

In the present study, highest densities of mosquito larvae were recorded in sewage water, the organically rich habitat. In contrast relatively lower densities were recorded in both drainage and released water bodies which were characterized by low organic matter content. The shading of drainage water by plants declined water temperature resulting in slow weed decomposition (Bambaradeniya and Amerasinghe, 2003) and reduction in algae growth which in turn reduced the availability of larval food (Al-Shami et al, 2009). Alternatively, the high water level in drainage canals may have also diluted the amount of organic matter and nutrients in general. Low population density of mosquito larvae in derange water could be also related to the toxic effect of certain chemical insecticide applied during the study period. Also, subjection of released water to weak light as a result of being surrounded by buildings caused reduction in plantation growth leading to low level of organic matter.

Many Egyptian reports (Mikhail et al, 2009, Kenawy, 1990, Kenawy et al, 1987, El Bahnasawy et al, 2013) found that $C x$. pipiens was the commonest species. The present results proved that $C x$. pipiens larvae survive at all the recorded $\mathrm{pH}$ values reached their maxi- mum density peak at the neutral $\mathrm{pH}$ (77.3).

The concentrations (conc.) of heavy metals varied in the three habitats. The factors underlying these differences may be complex. Further studies are needed on the sources of pollutants, soil composition particularly the physical and chemical characteristics, precipitation patterns, and composition of flora growing in the study areas. Elevated levels of heavy metals observed in sewage water, underscores the anthropogenic nature of heavy metals pollution in the study areas. The positive correlations observed between the heavy metals concentrations in the three habitats suggested relative uniformity of the sources of metal pollutants (Onyri and Wandiga, 1989; Okoy et al, 1991; Mireji et al, 2008). The presence of significantly high densities of $C x$. pipiens larvae under these elevated levels of heavy metals suggests their high tolerance to heavy metals in the three habitats particularly in sewage water. It may be also due to beneficial and compensatory effects of high nutrient levels associated with sewage or domestic waste present (Clements and Kifney, 1994; Reroldi et al, 1997). The aquatic insects chronically exposed to heavy metals were previously reported 
to exhibit increased tolerance relative to native population (Klerks and Weis, 1987; Krantzberg and Stoks, 1990; Hare, 1992; Pagliara and Stabili, 2012).

Previous studies demonstrated greater tolerance of culicines to elevated levels of heavy metals in different habitats (Linthicum, 2012). Though culicine larvae are greatly opportunistic and widely distributed in the three studies habitats, in contrast anophline larvae were only recorded in the relatively less polluted habitats with sand or mud substrates (released and drainage water). Previous studies showed that anophiline immature stages are generally thought to occur in clean sunlit habitats (Gillett, 1972; Chavasse et al, 1995; Service, 1995).

The decreased densities of anopheline larvae during the present study may also be related to co-existence with high densities of culicine larvae in the same habitats which could result in competitive interactions. Impoinvil et al. (2008) showed that the crowded habitat with one mosquito species might prevent other mosquito species from colonizing the habitats. Furthermore, different habitat characteristics impact the extent to which these mosquitoes encounter one another, hence influencing interspecific species interaction (Lloyd, 1995).

\section{References}

Al-Shami, SA, Che Sahnah, MR, Abu Hassan, A, Azizah, MNS, 2009: Temporal distribution of larval chironomidae (Diptera) in experimental rice field in Penang, Malaysia. J. AsiaPacific Entomol. 1016-20
AOAC, 1995: Official Methods of Analysis $19^{\text {th }}$ ed., Association of Official Analytical Chemists: Washington DC.

APHA, 1985: Standard Methods for the Examination of Water and Wastewater $16^{\text {th }}$ ed American Public Health Association, Washington DC.

APHA, 1989: Standard Methods for Examination of Water and Wastewater $17^{\text {th }}$ ed. Greenberg, AE, Clesceri, LS, \& Eaton, AD. (eds.) Washington, DC.

Bambaradeniya, $C$, Amerasinghe, $F$, 2003: Biodiversity associated with rice field agro-ecosystem in Asian countries: A brief review. Working paper 3 Colombo Sri Lanka: International Water Management Institute.

Chavasse, DC, Lines, JD, Lvhimori, K, Marijuana, J, 1995: Mosquito control in Dar Es-salaam I assessment of Culex quinquefasciatus breeding site prior to intervention. Med. Vet. Entomol. 9:141-6.

Clements, WH, Kifney, PM, 1994: Integrated laboratory and field approach for assessing impact of heavy metals at the Arkansas River, Colorado. Environ. Toxicol. Cherm. 7:715-22.

Clements AN, 1999: Biology of Mosquitoes. $2^{\text {nd }}$ ed, Chapman $\&$ Hall, London.

El-Bahnasawy, MM, Khater, MMK, Morsy, TA, 2013: Mosquito borne west Nile virus infection: Is it threating to Egypt or a neglected endemic disease? J. Egypt. Soc. Parasitol. 43, 1:87-102. Gad, AM, 1963: Insect of Medical Importance (in Arabic). Inst. Med. Entom. The Ministry of Health, Dokki, Egypt. 
Gillett, J, 1972: Common African Mosquitoes and their Medical Importance Bull. WHO, Geneva.

Hare, L, 1992: Aquatic insects and trace metals: Bioavailability bioaccumulation and toxicity. Crit. Rev. Toxicol. 22:327-69.

Impoinvil, DE, Keating, J, Mbogo, C M, Potts, MD., Chowdhury, RR, et al, 2008: Abundance of immature Anopheles and culicines (Diptera: Culicidae) in different water body types in the urban environment of Malindi, Kenya. J. Vector Ecol. 33:107-16.

Jackson, ML, 1998: Soil Chemical Analysis Prentice Hall, Inc., Englewood Chaffs New Jersey, Library of Congress, USA.

Kenawy, MA, 1990: Fauna of Anopheline mosquitoes (Diptera: Culicidae) in A.R. Egypt: Historical back-ground and present situation. J. Egypt. Publ. Hlth. Assoc. 65, 3/4: 263-81.

Kenawy, MA, Beier, JC, Zimmerman, JH, EI Said, S, Abbassy, MM, 1987: Host feeding patterns of the mosquito community (Diptera: Culicidae) in Aswan Governorate, Egypt. J. Med. Entomol. 24:35-9.

Klerks, PL, Weis, JS, 1987: Genetic adaptation to heavy metals in aquatic organisms a review. Environ. Pollut. 45:173-205.

Krantzberg, G, Stokes, PM, 1990: Metal concentrations and tissues distribution in larvae of Chironomus with reference to X-ray microprobe analysis. Arch. Environ. Contam. Troxicol. 19: 84-93.

Linthicum, KJ, 2012: Summary of the symposium global perspective on the
Culex pipiens complex in the $21^{\text {st }}$ Century: Interrelationship of Culex pipiens, quinquefasciatus, molestus \& others. J. Am. Mosq. Cont. Assoc. 28, 4: S152-5. Lloyd, M, 1995: Mean crowding. J. Anim. Ecol. 36:1-30.

Mikhail, MW, Al-Bursheed, KhM, Abdel-Halim, AS, Morsy, TA, 2009: Studies on mosquito borne diseases in Egypt and Qatar. J. Egypt. Soc. Parasitol. 39, 3:745-56.

Mireji, PO, Keating, J, Hassanali, A, Mbogo, C, Nyambaka, H, et al, 2008: Heavy metals in mosquito larval habitats in urban Kisumu and Malindi, Kenya and their impact. Ecotoxicol. Environ. Safety 70:147-53.

Mwangangi, JM, Muturi, EJ, Mbogo, CM, 2009: Seasonal mosquito larval abundance and composition in Kibwezi, lower eastern Kenya. J. Vector Borne Dis. 46: 65-71.

Okoye, BCO, Afolabi, OA, Ajao, EA, 1991: Heavy metals in Lagos lagoon sediments. Int. J. Environ. Stud. 37:3541.

Onyari, J.M, Wandiga, S.O, 1989: Distribution of $\mathrm{Cr}, \mathrm{Pb}, \mathrm{Cd}, \mathrm{Zn}, \mathrm{Fe}$ and $\mathrm{Mn}$ in Lake Victoria sediments, East Africa. Bull. Environ. Contam. Toxicol. 42:807-13.

Page, AL, Miller, RH, Kenny, DR, 1982: Methods of soil analysis. Part 2: Chemical and Microbiological Properties. $2^{\text {nd }}$ ed.; American Society of Agronomy, Madison.

Renoldi, M, Camusso, M, Tartari, G, 1997: The highly polluted Lambro River (North Italy): Dissolved and solid transport of $\mathrm{Cu}, \mathrm{Cr}$ and $\mathrm{Fe}$. Water Oil Soil Pollut. 95:99-118. 
Pagliara, P, Stabili, L, 2012: Zinc effect on sea urchin Paracentrotus livi$d u s$ immunological competence. Chemosphere 89, 5:563-8.

Richard, LD, 1954: Diagnosis and Improvement of Saline and Alkali Soils. Handbook, No. 60, USA.

Seing, J, Mbogo, CM., Potts, MD, Chowdrvice, MW, 1996: Medical Entomology for Students. Chapmen and Hall, London.

Serice, MW, 1989: The importance of ecological studies on malaria vectors. Bull. Soc. Vector Ecol. 14: 26-38.

Serice, MW, 1995: Can we control mosquitoes with pesticides? J. Am. Mosq. Cont. Assoc. 11: 290-3.

Tribouth, H, 1970: Die Bedeutung der erweiteren Tofrakionierurg fur die genauere Kennzeichung des Mineralbestandes und siner Eigenschaften. Zpflanzenem. Bodenk, 126: 117-34.

WHO, 1975: Manual on Practical Entomology in Malaria Part-II, Geneva

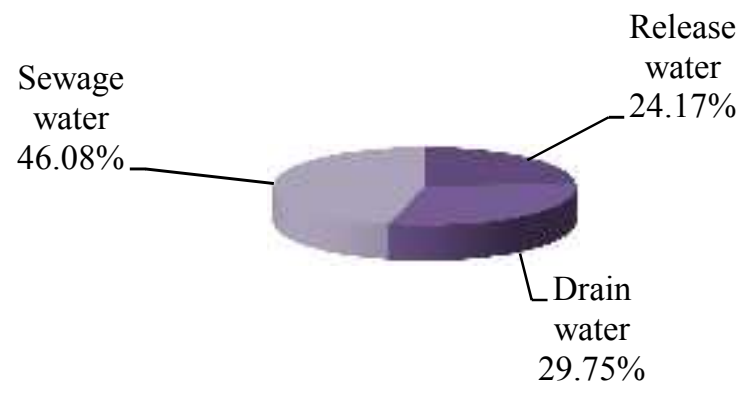

Figure 2: Larval abundance in three studied habits

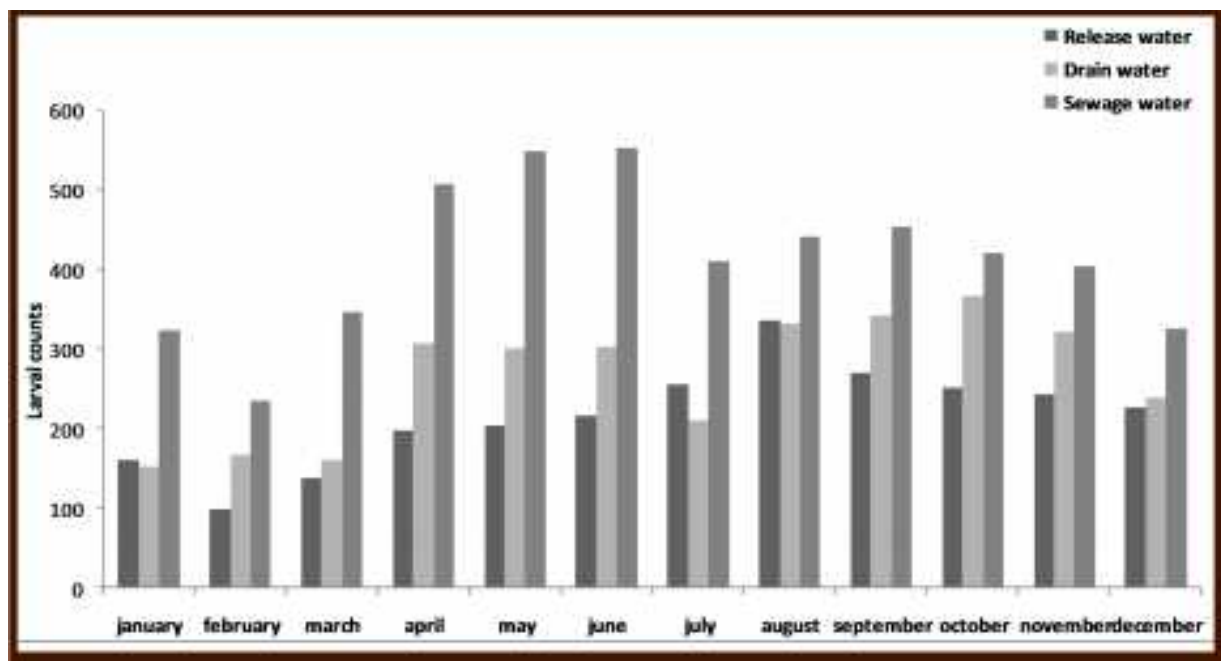

Figure 3: Abundance of Culex pipiens larvae in the 3 studied habitats. 